\title{
Game Based Pedagogy System for Assessment using Features Like OCR and Speech-To-Text Recognition
}

\author{
Aakash Jain, Parth Shah, Anish Punamiya, Shahzia Sayyad
}

\begin{abstract}
Game-based learning is an approach to learning where gaming concepts are implemented in learning tasks designed by teachers. Here, learning activities boost a student's commitment and inspiration to learn. Components of game-based learning include quizzes, point systems, leader boards, and classroom response systems. With the advancements in the field of education, game-based learning has proven that it is a utilitarian option in improving a student's assessment where paper-based evaluation is not possible. Various Game-Based Learning Systems have been built previously and, in this paper, we have compared 11 existing models based on various factors like cost, quiz customization options, mobile support, etc. We have also pointed out the benefits and limitations of these systems. None of these systems give a complete set of all the features without being exorbitantly costly. So, we aspire to assemble a credible teaching project where all aspects would be included in a single application for the complete assessment of every student. The system has several key features like OCR, Speech to Text recognition, anti-cheating tools, and feedback after the quiz. For executing OCR, we have used OpenCV because of its extensive admiration and for Speech-to-Text Recognition (STR), we have adopted the SpeechRecognition library because it is quite adaptable. This system aims at reducing the workload of teachers by creating a test by scanning the questions with the help of OCR or by using STR so the teacher need not type the question and also by assessing students based on their scores.
\end{abstract}

Keywords: Game Pedagogy System, Game-Based Learning, Online Learning, Educational Learning, Formative Assessment.

\section{INTRODUCTION}

Game-based learning can be defined as the borrowing of a few gaming principles and using them to real-life settings to engage students. The motivational psychology associated with game-based learning allows students to

Revised Manuscript Received on October 24, 2020

*Correspondence Author

Aakash Jain*, Student of Dept. of Computer Engineering, Shah and Anchor Kutchhi Engineering College, Mumbai, Maharashtra, India. Email: aakash.jain@sakec.ac.in.

Parth Shah, Student of Dept. of Computer Engineering, Shah and Anchor Kutchhi Engineering College, Mumbai, Maharashtra, India. Email: parth.shah_2017@sakec.ac.in.

Anish Punamiya, Student of Dept. of Computer Engineering, Shah and Anchor Kutchhi Engineering College, Mumbai, Maharashtra, India. Email: anish.punamiya@sakec.ac.in.

Shahzia Sayyad, Assistant Professor, Dept. of Computer Engineering, Shah and Anchor Kutchhi Engineering College, Mumbai, Maharashtra, India. Email: shahzia.sayyad@sakec.ac.in.

(c) The Authors. Published by Blue Eyes Intelligence Engineering and Sciences Publication (BEIESP). This is an open access article under the CC BY-NC-ND license (http://creativecommons.org/licenses/by-nc-nd/4.0/) engage with educational materials in an energetic and dynamic way.

It can be difficult to keep students involved and inspired to understand complicated concepts; this is especially true if the challenge seems daunting and new to students and in times of pandemic in which multiple improvements have been made in the field of education this task is even more challenging. As of September 2020, approximately 1.277 billion learners are currently affected because of school closures in response to the COVID pandemic. As per UNICEF, 46 countries are currently implementing nationwide closures and 27 are implementing local closures, impacting about 72.9 percent of the world's student population [20]. It is practically impossible for students to attend the college physically or to even appear for a pen-paper based test. This arises the need of a system where the learning process takes place through different and attractive scenarios for overcoming various challenges and where the learning experience is positive and interesting. In such a technology-oriented environment where everything happens online, Game-based student response systems (GSRS) are becoming prevalent. There are several existing GSRS but none of them can be considered as completely feasible. Most systems are either very expensive for any Institute to incorporate or do not have all the features which are needed. A feasible Game-Based Learning System is required where the instructor plays the role of a game host and the students are the players. The games will be beneficial for academic achievement of students by monitoring a healthy competition amongst them, motivating them to perform better than others and improving classroom dynamics by constant engagement in the class. The system will help to improve the performance of the student by providing an adaptive learning platform. It allows the teacher to know the shortcomings of his/her students and where the teacher needs to work upon in order to fulfil the role of an intellect developer. We endeavour to combine different techniques for better results.

\section{MOTIVATION}

The main inspiration for this project is our honourable Prime Minister Shri. Narendra Modiji's vision of Atma Nirbhar Bharat, making India a self-reliant nation. With that vision in mind, the system's ultimate aim would be assessment of every student based on adaptive learning by making an unbiased judgement on the overall performance of the student.

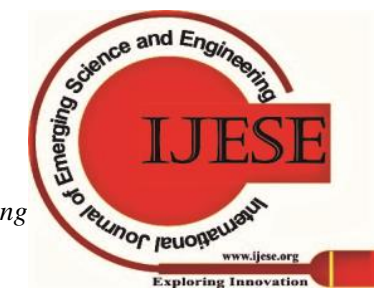


With the ongoing advancements, a tipping point may just be a couple of years away where adaptive learning becomes a standard and expected offering rather than the relative reality.

\section{RELATED WORK}

With the advancements in Technology being used in Education, there are several existing systems present which are extensively used worldwide. Out of which, we have studied 11 existing systems-

- Kahoot [9]

- Quizziz [10]

- Google Form [11]
- Socrative [12]

- Classtime [13]

- Gimkit [14]

- Bookwidget [15]

- Quizlet [16]

- Formative [17]

- Mentimeter [18]

- Polleverywhere [19]

The features of these systems are compared according to 3 modules which are:

- Student

- Teacher

- Result

Table-I: Student module

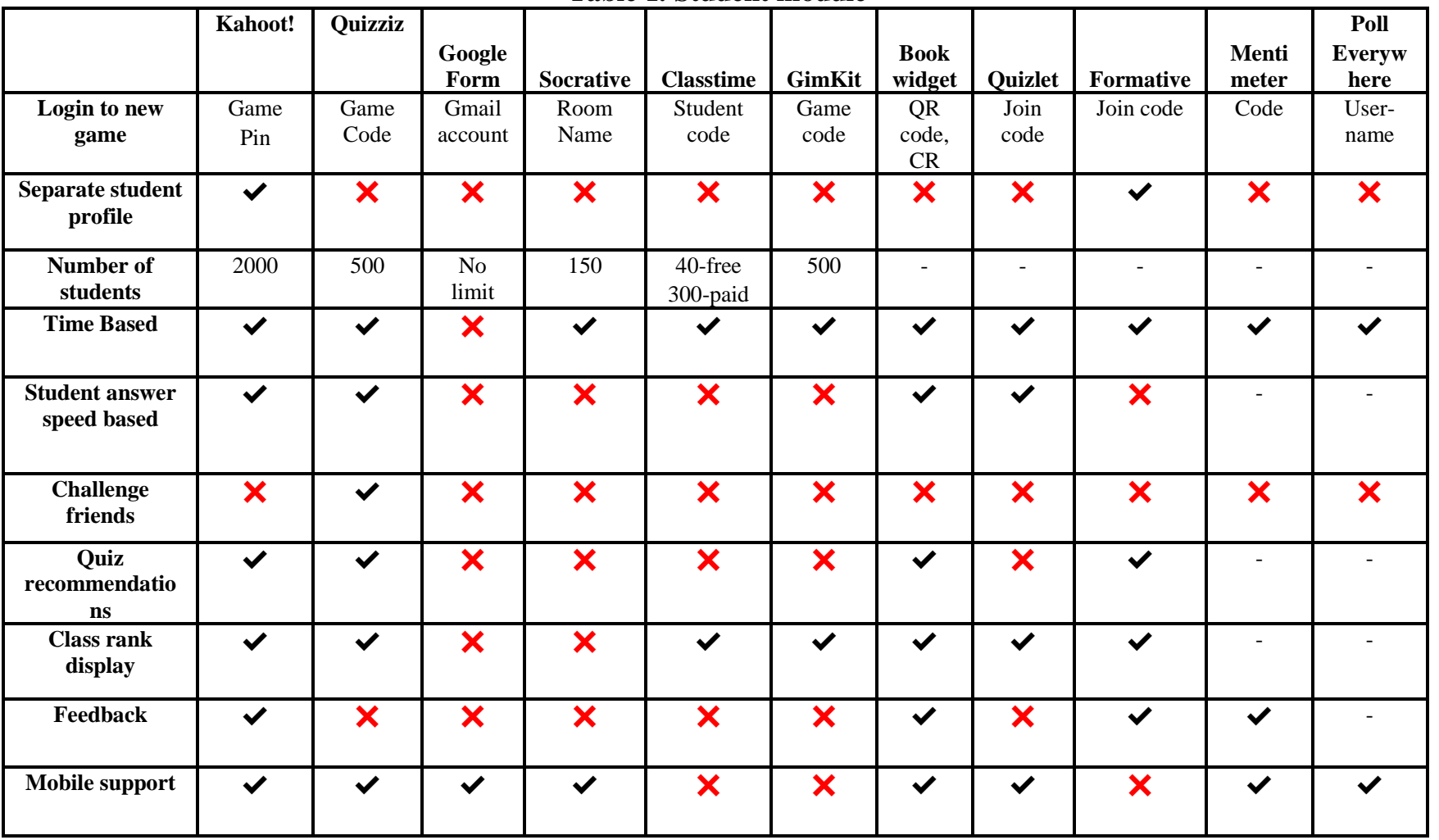

Table-II: Teacher Module

\begin{tabular}{|c|c|c|c|c|c|c|c|c|c|c|c|}
\hline & \multirow[t]{2}{*}{ Kahoot! } & \multirow[t]{2}{*}{ Quizziz } & \multirow{2}{*}{$\begin{array}{l}\text { Google } \\
\text { Form }\end{array}$} & \multirow[b]{2}{*}{ Socrative } & \multirow[b]{2}{*}{ Classtime } & \multirow[b]{2}{*}{ GimKit } & \multirow{2}{*}{$\begin{array}{c}\text { Book } \\
\text { widget }\end{array}$} & \multirow[b]{2}{*}{ Quizlet } & \multirow[b]{2}{*}{ Formative } & \multirow{2}{*}{$\begin{array}{l}\text { Menti- } \\
\text { meter }\end{array}$} & \multirow{2}{*}{$\begin{array}{l}\text { Poll } \\
\text { Everywhere }\end{array}$} \\
\hline & & & & & & & & & & & \\
\hline Add rich & \multirow[t]{2}{*}{$\checkmark$} & \multirow[t]{2}{*}{$\checkmark$} & \multirow[t]{2}{*}{$\checkmark$} & \multirow[t]{2}{*}{$\checkmark$} & \multirow[t]{2}{*}{$\mathrm{X}$} & \multirow[t]{2}{*}{$\mathrm{X}$} & \multirow[t]{2}{*}{ X } & \multirow[t]{2}{*}{$\checkmark$} & \multirow[t]{2}{*}{$\checkmark$} & \multirow[t]{2}{*}{$x$} & \multirow[t]{2}{*}{$\checkmark$} \\
\hline $\begin{array}{l}\text { text } \\
\text { formatting }\end{array}$ & & & & & & & & & & & \\
\hline $\begin{array}{l}\text { Import quiz } \\
\text { from excel } \\
\text { sheet }\end{array}$ & $\checkmark$ & $\checkmark$ & $x$ & $\checkmark$ & $x$ & $\checkmark$ & $\checkmark$ & $\checkmark$ & $x$ & $\checkmark$ & $\checkmark$ \\
\hline $\begin{array}{l}\text { Add math } \\
\text { equation/ }\end{array}$ & $\checkmark$ & $\checkmark$ & $x$ & $\checkmark$ & $x$ & $\checkmark$ & $x$ & $x$ & $\checkmark$ & $x$ & $x$ \\
\hline Symbols & & & & & & & & & & & \\
\hline $\begin{array}{l}\text { Quiz } \\
\text { preview }\end{array}$ & $\checkmark$ & $\checkmark$ & $\checkmark$ & $x$ & $\checkmark$ & $x$ & $\checkmark$ & $x$ & $\checkmark$ & $\checkmark$ & $x$ \\
\hline $\begin{array}{l}\text { Quiz } \\
\text { arranged in } \\
\text { folders }\end{array}$ & $x$ & $\checkmark$ & $\checkmark$ & $\checkmark$ & $x$ & $x$ & $\checkmark$ & $\checkmark$ & $\checkmark$ & $\checkmark$ & $\checkmark$ \\
\hline
\end{tabular}




\begin{tabular}{|c|c|c|c|c|c|c|c|c|c|c|c|}
\hline Rationale & $\mathrm{X}$ & $x$ & $\mathrm{X}$ & $\checkmark$ & $\checkmark$ & $x$ & $\checkmark$ & $\mathrm{X}$ & $x$ & $\mathrm{X}$ & $\mathrm{X}$ \\
\hline Byte limit & \multirow[t]{2}{*}{120} & \multirow{2}{*}{$\begin{array}{l}\text { No } \\
\text { limit }\end{array}$} & \multirow{2}{*}{$\begin{array}{l}\text { No } \\
\text { limit }\end{array}$} & No & \multirow[t]{2}{*}{170} & \multirow[t]{2}{*}{220} & No & No & No & \multirow[t]{2}{*}{150} & \multirow[t]{2}{*}{256} \\
\hline for question & & & & limit & & & limit & limit & limit & & \\
\hline Live Quiz & $\checkmark$ & $\checkmark$ & $x$ & $\checkmark$ & $\checkmark$ & $\checkmark$ & $\checkmark$ & $x$ & $\checkmark$ & $\checkmark$ & $x$ \\
\hline Self-Learn & $\checkmark$ & $\checkmark$ & $\checkmark$ & $x$ & $x$ & $\checkmark$ & $x$ & $\checkmark$ & $\checkmark$ & $x$ & $\checkmark$ \\
\hline Add Image/ & \multirow[t]{2}{*}{$\checkmark$} & \multirow[t]{2}{*}{$\checkmark$} & \multirow[t]{2}{*}{$\begin{array}{l}\text { No } \\
\text { audio }\end{array}$} & \multirow[t]{2}{*}{$\begin{array}{l}\text { Only } \\
\text { image }\end{array}$} & \multirow[t]{2}{*}{ No audio } & \multirow[t]{2}{*}{$\checkmark$} & \multirow[t]{2}{*}{$\checkmark$} & \multirow[t]{2}{*}{$x$} & \multirow[t]{2}{*}{$\checkmark$} & \multirow[t]{2}{*}{$\begin{array}{l}\text { Only } \\
\text { image }\end{array}$} & \multirow[t]{2}{*}{ Only image } \\
\hline Audio/Video & & & & & & & & & & & \\
\hline Launching & \multirow{2}{*}{$\begin{array}{l}\text { Via } \\
\text { code }\end{array}$} & \multirow{2}{*}{$\begin{array}{l}\text { Via } \\
\text { code }\end{array}$} & \multirow{2}{*}{$\begin{array}{l}\text { Via } \\
\text { link }\end{array}$} & \multirow[t]{2}{*}{ Via code } & \multirow[t]{2}{*}{ Via code } & \multirow{2}{*}{$\begin{array}{l}\text { Via } \\
\text { code }\end{array}$} & \multirow{2}{*}{$\begin{array}{l}\text { Via } \\
\text { code }\end{array}$} & \multirow{2}{*}{$\begin{array}{l}\text { Via } \\
\text { Link }\end{array}$} & \multirow[t]{2}{*}{ Via code } & \multirow{2}{*}{$\begin{array}{l}\text { Via } \\
\text { code }\end{array}$} & Via \\
\hline the Ouiz & & & & & & & & & & & Link \\
\hline $\begin{array}{l}\text { Randomize } \\
\text { options/ } \\
\text { questions }\end{array}$ & $\checkmark$ & $\checkmark$ & $\checkmark$ & $x$ & $x$ & $\mathrm{x}$ & $\checkmark$ & $x$ & $\checkmark$ & $x$ & $x$ \\
\hline
\end{tabular}

Table-III: Result Module

\begin{tabular}{|c|c|c|c|c|c|c|c|c|c|c|c|}
\hline & Kahoot! & Quizizz & $\begin{array}{l}\text { Google } \\
\text { Form }\end{array}$ & Socrative & Classtime & GimKit & $\begin{array}{l}\text { Book } \\
\text { widget }\end{array}$ & Quizlet & Formative & $\begin{array}{l}\text { Menti } \\
\text { meter }\end{array}$ & $\begin{array}{c}\text { Poll } \\
\text { Everywhere }\end{array}$ \\
\hline Key Stats & $\checkmark$ & $\checkmark$ & $\checkmark$ & $\checkmark$ & $\checkmark$ & $\checkmark$ & $\checkmark$ & $\checkmark$ & $\checkmark$ & $\checkmark$ & $\checkmark$ \\
\hline $\begin{array}{l}\text { Time } \\
\text { Record }\end{array}$ & $\checkmark$ & $\checkmark$ & $\checkmark$ & $x$ & $x$ & $x$ & $x$ & $x$ & $x$ & $x$ & $x$ \\
\hline $\begin{array}{l}\text { Avg. } \\
\text { Question } \\
\text { Time } \\
\text { Taken }\end{array}$ & $\checkmark$ & $\checkmark$ & $x$ & $x$ & $x$ & $x$ & $x$ & $x$ & $x$ & $x$ & $x$ \\
\hline $\begin{array}{l}\text { Avg. Quiz } \\
\text { Time }\end{array}$ & $\checkmark$ & $\checkmark$ & $x$ & $x$ & $x$ & $x$ & $x$ & $x$ & $x$ & $x$ & $x$ \\
\hline $\begin{array}{l}\text { Question } \\
\text { View }\end{array}$ & $\checkmark$ & $\checkmark$ & $\checkmark$ & $\checkmark$ & $x$ & $x$ & $x$ & $x$ & $x$ & $x$ & $\checkmark$ \\
\hline $\begin{array}{l}\text { Student } \\
\text { View }\end{array}$ & $\checkmark$ & $\checkmark$ & $\checkmark$ & $\checkmark$ & $x$ & $x$ & $x$ & $x$ & $x$ & $x$ & $\checkmark$ \\
\hline $\begin{array}{l}\text { Overall } \\
\text { Report }\end{array}$ & $\checkmark$ & $\checkmark$ & $x$ & $\checkmark$ & $\checkmark$ & $x$ & $\checkmark$ & $\checkmark$ & $\checkmark$ & $\checkmark$ & $\checkmark$ \\
\hline $\begin{array}{l}\text { Top } \\
\text { Scorers }\end{array}$ & $\checkmark$ & $\checkmark$ & $x$ & $x$ & $x$ & $x$ & $x$ & $x$ & $x$ & $x$ & $x$ \\
\hline $\begin{array}{l}\text { Least } \\
\text { Scorers }\end{array}$ & $\checkmark$ & $x$ & $x$ & $x$ & $x$ & $x$ & $x$ & $x$ & $x$ & $x$ & $x$ \\
\hline Re-Quiz & $\checkmark$ & $x$ & $x$ & $x$ & $x$ & $x$ & $x$ & $x$ & $x$ & $x$ & $x$ \\
\hline $\begin{array}{l}\text { Difficult } \\
\text { Questions }\end{array}$ & $\checkmark$ & $x$ & $x$ & $x$ & $x$ & $x$ & $x$ & $x$ & $x$ & $x$ & $x$ \\
\hline $\begin{array}{l}\text { Chart } \\
\text { View }\end{array}$ & $\checkmark$ & $\checkmark$ & $x$ & $\checkmark$ & $\checkmark$ & $x$ & $\checkmark$ & $\checkmark$ & $\checkmark$ & $\checkmark$ & $\checkmark$ \\
\hline $\begin{array}{l}\text { Rename \& } \\
\text { Arrange } \\
\text { Report }\end{array}$ & $\checkmark$ & $x$ & $x$ & $\checkmark$ & $\checkmark$ & $x$ & $\checkmark$ & $\checkmark$ & $\checkmark$ & $\checkmark$ & $\checkmark$ \\
\hline Download & $\checkmark$ & $\checkmark$ & $\checkmark$ & $\checkmark$ & $\checkmark$ & $x$ & $\checkmark$ & $\checkmark$ & $\checkmark$ & $\checkmark$ & $\checkmark$ \\
\hline
\end{tabular}

Retrieval Number:100.1/ijese K24821061120
Published By:

Blue Eyes Intelligence Engineering \& Sciences Publication

(c) Copyright: All rights reserved. 
Table-IV: Cost Analysis of Existing Systems

\begin{tabular}{|c|c|}
\hline System & Price \\
\hline Kahoot! & Plus-120\$ per year \\
& Pro-199 $\$$ per year \\
\hline Quizizz & FREE \\
\hline Google Form & FREE \\
\hline Socrative & Basic-Free \\
& Pro-60 $\$$ per year \\
\hline Class Time & $60 \$$ per year \\
\hline Gimkit & $60 \$$ per year \\
\hline Bookwidget & Students-Free \\
& Teachers-\$49 \\
\hline Quizlet & \$20 per year \\
\hline Formative & Premium-\$12 per month \\
\hline Mentimeter & Basic-\$10 per month \\
& Pro-\$25 per month \\
\hline Polleverywhere & Basic-\$42 per month \\
& Small Team-\$84 per month \\
& Enterprise-\$999+ \\
\hline
\end{tabular}

Table-V: Findings

\begin{tabular}{|c|c|}
\hline Title & Finding \\
\hline $\begin{array}{l}\text { Using Kahoot! in the classroom } \\
\text { to create engagement and active } \\
\text { learning [3] }\end{array}$ & $\begin{array}{l}\text { Our experience with Kahoot! reinforces that this eLearning platform can provide an } \\
\text { engaging environment that supports learning and adds active classroom } \\
\text { participation with some effort and a desire to engage students. }\end{array}$ \\
\hline $\begin{array}{l}\text { Kahoot! Or Quizizz- } \\
\text { Student Perspective [2] }\end{array}$ & $\begin{array}{l}\text { With Kahoot! and Quizizz the students are engaged, addicted and motivated to learn } \\
\text { and achieve better. The one and the main point which makes Kahoot! better than } \\
\text { most of the other systems is that it allows students to lively collaborate and compete } \\
\text { among groups in an energetic classroom atmosphere. }\end{array}$ \\
\hline $\begin{array}{l}\text { Analyzing the Efficacy of the } \\
\text { Testing effect Using Kahoot! on } \\
\text { Student Performance [1] }\end{array}$ & $\begin{array}{l}\text { Students also felt that when taking the high-stakes examination, being exposed to } \\
\text { questions leading up to the exam helped them feel more comfortable. Students also } \\
\text { mentioned that they were looking forward to class because they liked to play. } \\
\text { Kahoot! helped them memorize key concepts. }\end{array}$ \\
\hline $\begin{array}{l}\text { Student Assessment of the use } \\
\text { of Kahoot! in the Learning } \\
\text { Process of Science and } \\
\text { Mathematics [11] }\end{array}$ & $\begin{array}{l}\text { In the classroom, an atmosphere is created based on motivation and improvement in } \\
\text { the acquisition of new content, which always involves an adequate teacher control } \\
\text { system and group-class characteristics. }\end{array}$ \\
\hline $\begin{array}{l}\text { The Effect of Kahoot! Quiz on } \\
\text { Students result in Exam [8] }\end{array}$ & $\begin{array}{l}\text { At the end of each class, a Kahoot! quiz performed weekly tended to help students } \\
\text { remember and choose the correct answers for the exam questions. The effectiveness } \\
\text { of the learning process of the students was therefore improved by participating in } \\
\text { Kahoot! quizzes }\end{array}$ \\
\hline $\begin{array}{l}\text { Quizizz Online Digital System } \\
\text { Assessment [9] }\end{array}$ & $\begin{array}{l}\text { The outcomes of the test answers and their analysis can be quickly found by Quizizz. } \\
\text { Students evaluate that Quizizz is enjoyable, allows them to review subject matter } \\
\text { and stimulates their interest in learning because there is a ranking of test results so } \\
\text { that they have a strong desire to compete to be at the top. }\end{array}$ \\
\hline $\begin{array}{l}\text { Perceptions of Students for } \\
\text { Gamification Approach [10] }\end{array}$ & $\begin{array}{l}\text { The information indicates that learning gamification increases the interest of } \\
\text { students in the lesson and encourages students to become more ambitious for } \\
\text { success. Simultaneously, the inclusion of approached gamification has a positive } \\
\text { impact on student motivation. These kinds of e-learning tools provide classroom } \\
\text { entertainment, supportive concept, and positive energy that appears to be } \\
\text { transformed into motivation and increasing significance. }\end{array}$ \\
\hline
\end{tabular}




\section{A. Advantages of existing systems}

1. Kahoot, Quizziz, Google Form, Gimkit, Quizlet, and Formative provide very useful features like practice quizzes.

2. Systems like Kahoot, Quizziz, and Socrative provide a competitive environment for students.

3. Kahoot and Quizziz provide the students with information and quizzes on a variety of subjects.

4. All Systems gives a detailed report to the Teacher about the performances.

5. Kahoot, Quizziz, Socrative, and Bookwidget makes use of sophisticated dynamic graphics which helps to obtain more clarity for an individual.

\section{B. Limitations of existing systems}

1. In Socrative the answers can only be true or false, Short answer or multiple choice. This can be a limitation because there are other options like a long paragraph, multiple selections, numeric entry helps to enhance the experience of testing better for students.

2. In apps like Kahoot and Quizizz, since students receive more points for quicker answers, it can emphasize speed over substance. The fact that "Kahoot!" gives extra credit has an emphasis on reaction time rather than pure knowledge is unfair, because some people might know the material in the games just as well, but not have the reaction time to win extra points for their better grades.

3. Kahoot requires a common interface to play, and this is only possible in classrooms, and if there is a video lecture going on which is the case in today's time due to COVID-19, but the students would require two devices which is a privilege not all students have hence a common interface would be difficult.

4. Questions and options have limit up to 120 characters in Kahoot! this can prevent teachers to enter long questions or long options if they want to.

5. Systems like Polleverywhere, Socrative, Gimkit and Classtime and Kahoot which has many of features is not suitable perfectly for all the Institutes to use, because it is expensive and the free version has limited features.

6. Though Quizziz and Google Forms are free and has many features that other systems have. However, Cheating is possible in systems like Quizziz because with the help of web extensions like Easy Script Hub students can get answers to the questions and in Google Forms the students can share each other the answers to the question therefore cheating is possible in both the systems which won't allow a just evaluation of students.

7. Students can appear for a quiz with false names in many systems and the teacher won't know if the user is genuine or he is just trying to cheat by entering a false name.

8. The design customization for the quiz is very limited in Google Forms. If the users could change the font and style of the text than it could be more interactive for students

9. The teacher does not get a tabular report of each student in systems like Gimkit.

\section{PROPOSED SYSTEM}

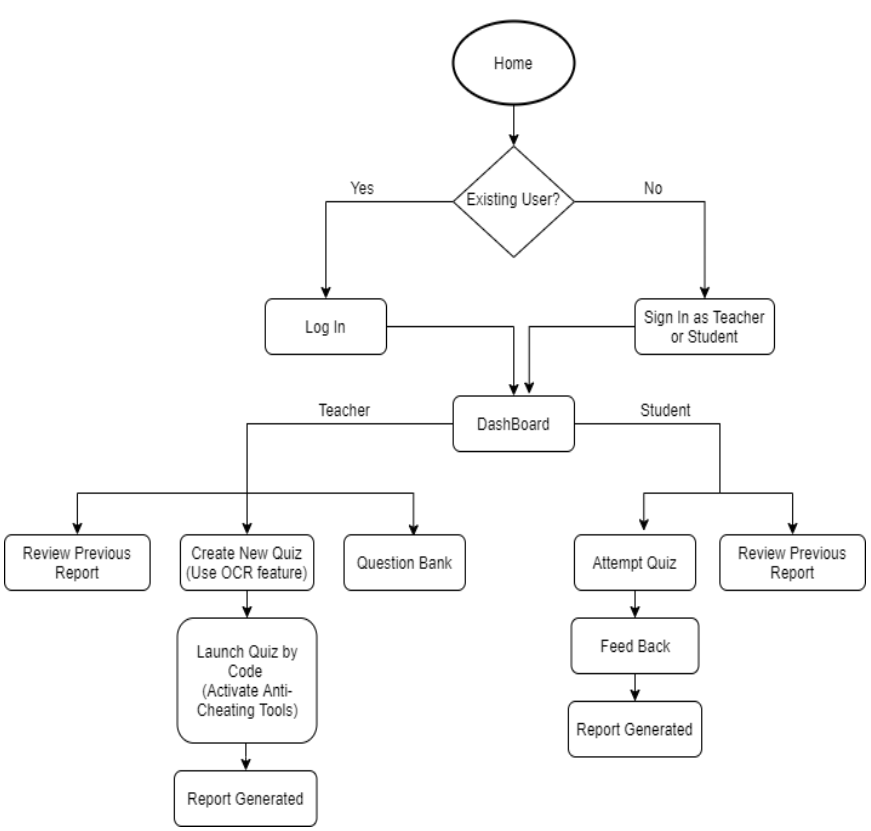

Figure 1. Flowchart of the Proposed Model

The proposed system has two type of user accounts-Teacher and Student Account. These two accounts will differ from each other in their features. After validating the account, the Teacher will be guided to the Dashboard which has different features like checking Previous Reports, Download Reports, Question Bank where they can view and add questions and create Quiz. The system will allow the teacher to add different types of questions in the quiz namely Fill in The Blanks, Multiple Choice Questions, Multiple Answers, Long Answers, etc. along with time constraints. After creating the quiz, the quiz can be launched by the teacher by sharing the code or link with the students. Once the student enters the code or clicks the link he/she will be validated by the organizer. After the quiz, a detailed tabular report will be generated for entire group of participants as well as individual participants, showing several key points like accuracy, average time taken to answer, leaderboard, etc. If the account is of a Student, Dashboard will show him Reports of previously attempted Quizzes and to attempt a quiz by entering code or link. After the quiz is finished, the student will see a detailed report of his responses.

\section{A. Key Features}

1. Optical Character Recognition (OCR): This will help teachers in saving time as this model will identify characters of printed sentences and directly use them as questions.

2. Speech-To-Text Recognition (STR): This provides the additional functionality to read aloud, take Questions verbally and also take Answers Verbally. The model will recognise the speech in recorded answers and send to the test organiser as Text if required.

3. Feedback after Quiz.

4. Student can post queries to the teacher in comment section. 
5. Anti-cheating tools: This feature will provide authenticity of assessments and provide a secure environment for conducting them.

6. Secure Testing Environment: Students can use a built-in camera in the computer or a separate webcam and the camera can show a 180-degree or 360-degree view of the room, as required by the test organizers. The students will be monitored via camera by the test organizers for any malpractices.

7. Prevent Copy and Paste option during Assessments.

8. Terminate the assessment if multiple tabs or other applications detected on the test taker's system.

\section{B. Objectives}

The main objectives of the proposed system are:

1. Evaluate progress of every student based on a game-based learning system.

2. Easy creation of quizzes where questions can be selected from a pool of questions.

3. Adaptive and non-adaptive testing based on various parameters like time limit, question limit etc.

4. Giving Institutes and Companies a tool where mass test can be organised for assessments.

5. Providing a secure online platform for conducting exams.

6. To make learning a fun experience for students.

\section{IMPLEMENTATION}

\section{A. Optical Character Recognition (OCR)}

The OCR model automatically identifies characters through an optical mechanism. It is fit for perceiving printed text. The performance can be judged based on the quality of the documents to be scanned and the camera being used to capture the image. This innovation empowers devices to analyze, interpret scanned images and convert them to genuine electronic text. OCR feature will help test organizers to use text from articles, books directly rather typing them again. Many times, the questions or content is printed in books and to use it we need to type it which takes a lot of time. This will help organizers save time. OCR works in Browser by combining Python, OpenCV and OCR. space API. We need to send through their API a picture with the content we need to scan and it will return us the text scanned.

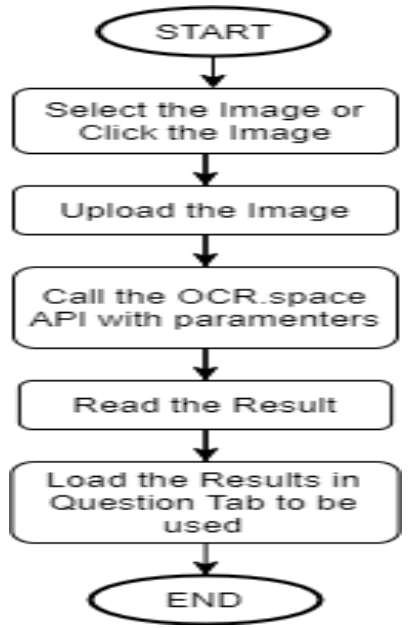

Figure 2. Flowchart of OCR
The OCR system allows for quick translation of image to text and does not require typing, editing data and memory utilization. OpenCV is chosen as the engine of the OCR because of its widespread approbation, extensibility, flexibility and suits well for browser-based models. To perform character recognition, the application has to go through four important steps which are as follows: -

1. Selecting or Clicking the Image: Device Camera can be used to capture the image of document or it can be selected from the device storage.

2. Uploading the Image: The image can be directly uploaded or it can be cropped to select only the specific area before uploading if required.

3. Call the API with Parameters

There are three parameters:

a. Url_api

b. Call "Files" which contains the name of the file and the file bytes we generated before after we compressed the image.

c. Call "Data" which contains the post parameters of the OCR engine.

4. Read the Result: The result from the server is a string and the result is read using JSON.

5. Load the Result in Question Tab Directly.

Results

Input 1-

\section{This is a test message for OCR Scanner Test}

Output 1-

Itext_detected.txt - Notepad
File Edit Format View Help
This is a test
message for
OCR Scanner
Test

Input 2-

MCQ. Bid quote is for
A. seller
B. buyer
C. hedger
D. speculator 
Output 2-

text_detected.txt - Notepad

File Edit Format View Help

MCQ. Bid quote is for
A. seller
B. buyer
C. hedger
D. speculator

\section{B. Speech-To-Text Recognition (STR)} electronic text. Speech must be converted from physical sound to an electrical signal with a microphone, and then to digital data with an analog-to-digital converter. This model will add oral question and answer dimensionality. This will provide different options to test organizers to test the test takers.

The Speech Recognition library is extremely flexible and supports the Google Web Speech API. This model requires audio input, Speech Recognition which makes retrieving this audio input easy and Google Voice Recognition Engine. Speech Recognition is chosen as it supports web applications.

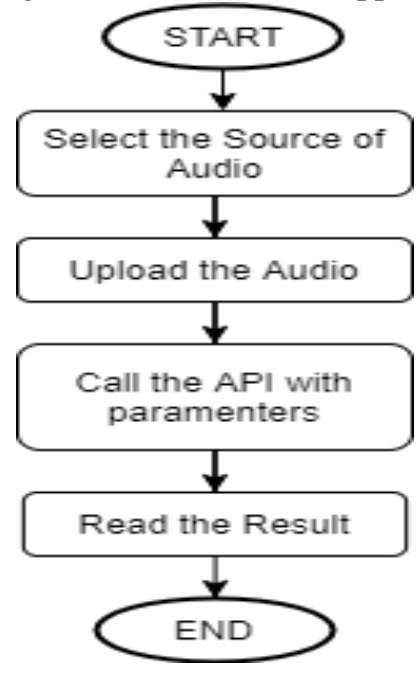

Figure 3. Flowchart of Speech-To-Text Recognition

To perform this recognition, the application has four important steps which are as follows:

1. Selecting the source of audio: The input to the SpeechRecognition module is of two types:

-Pre-recorded audio file

-Voice input through default Microphone

2. Uploading the Audio File

3. Call the API with parameters

There are three parameters: -

a. Source of the input

b. Time for which the microphone needs to accept and record the input audio.

c. The user will need to pass the language as a parameter to the function to change the language.
The Speech to Text model converts spoken words to

4. Read the Result: The result will be given in Text Form.

\section{CONCLUSION}

Game Based learning improves student commitment and engagement by making the learning experience playful and dynamic for overcoming various challenges. It plays an important role in teaching by making students collaborate, communicate and interact with the class. This research proposed the need of a new system of learning with various features like OCR, Speech-to-Text Recognition which can be very helpful for teachers in preparing any test paper by reducing the manual work of typing the questions and directly uploading them in any test or adding it to the pool of questions. Anti-cheating tools like the usage of camera can be used for constant assessment of students while they appear for test. All these features collectively aim to reduce the human efforts needed for a test creation and improve an individual's performance by continuous evaluation.

\section{REFERENCES}

1. Iwamoto, D. H., Hargis, J., Taitano, E. J., \& Vuong, K. (2017). Analyzing the Efficacy of the Testing Effect Using Kahoot ${ }^{\mathrm{TM}}$ on Student Performance. Turkish Online Journal of Distance Education, 18(2), 80-93

2. Basuki, Y., \& Hidayati, Y. (2019, April). Kahoot! or Quizizz: The Students' Perspectives. In Proceedings of the 3rd English Language and Literature International Conference (ELLiC) (2019)_Perspectives).

3. Plump, C. M., \& LaRosa, J. (2017). Using Kahoot! in the classroom to create engagement and active learning: A game-based technology solution for eLearning novices. Management Teaching Review, 2(2), 151-158.

4. Dervan, P. (2014). Increasing in-class student engagement using Socrative (an online Student Response System). All Ireland Journal of Higher Education, 6(3).

5. Awedh, M., Mueen, A., Zafar, B., \& Manzoor, U. (2015). Using Socrative and Smartphones for the support of collaborative learning. arXiv preprint arXiv:1501.01276

6. Llerena, Edison \& Hurtado, Carlos. (2017). Kahoot! A Digital Tool for Learning Vocabulary in a language Kahoot! A Digital Tool for Learning Vocabulary in a language classroom. Vol 4. 441-449.

7. Permana, Pepen \& Permatawati, Irma. (2020). Using Quizizz as a Formative Assessment Tool in German Classrooms. 10.2991/assehr.k.200325.073.

8. Tóth, Áron \& Lógó, Péter \& Emma, Lógó. (2019). The Effect of the Kahoot Quiz on the Student's Results in the Exam. Periodica Polytechnica. 10.3311/PPso.12464.

9. Kahoot, https://kahoot.com/ Accessed date: 18 June 2020

10. Quizziz, https://quizizz.com/ Accessed date: 18 June 2020

11. Google Form, https://www.google.com/forms/about/ Accessed date: 18 June 2020

12. Socrative, https://socrative.com/ Accessed date: 18 June 2020

13. Classtime, https://www.classtime.com/en/ Accessed date: 19 June 2020

14. Gimkit, https://www.gimkit.com/playAccessed date: 19 June 2020

15. Bookwidgets, https://www.bookwidgets.com/Accessed date: 19 June 2020

16. Quizlet, https://quizlet.com/ Accessed date: 19 June 2020

17. Formative, https://goformative.com/ Accessed date: 20 June 2020

18. Mentimeter, https://www.mentimeter.com/Accessed date: 20 June 2020

19. Polleverywhere, https://www.polleverywhere.com/ Accessed date: 20 June 2020

20. UNESCO, https://en.unesco.org/covid19/educationresponse Accessed date: 17 September 2020 
Game Based Pedagogy System for Assessment using Features Like OCR and Speech-To-Text Recognition

\section{AUTHORS PROFILE}

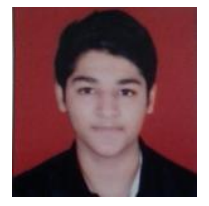

Aakash Jain, studying B.E final year in the stream of Computer Engineering at Shah and Anchor Kutchhi Engineering College, Mumbai, Maharashtra, India.

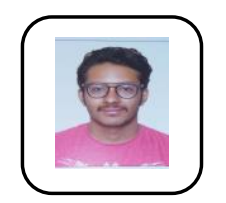

Parth Shah, studying B.E final year in the stream of Computer Engineering at Shah and Anchor Kutchhi Engineering College, Mumbai, Maharashtra, India.

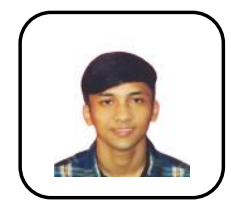

Anish Punamiya, studying B.E final year in the stream of Computer Engineering at Shah and Anchor Kutchhi Engineering College, Mumbai, Maharashtra, India.

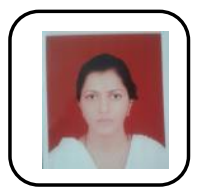

Shahzia Sayyad, received the B.E. and M.Tech. degree in Computer Science \& Engineering from the Visvesvaraya Technological University, Belgaum, Karnataka, in 2003 and 2011, respectively. She is an Assistant Professor in Shah and Anchor Kutchhi Engineering College, University of Mumbai. Her research interest includes Network Security, Privacy Preservation, Storage Area Network, Cloud Computing, Web Application Designing. She has published articles on Cloud Computing, Web Security and Deep learning in various journals. Shahzia Sayyad is a member of the Indian Society for Technical Education (ISTE). 